\title{
JAUNŲJŲ KREPŠININKŲ DAUGIAMEČIO (10-17 METŲ) ATLETINIO IR TECHNINIO PARENGTUMO RODIKLIAI
}

\author{
Kęstutis Matulaitis, Antanas Skarbalius, Kazimieras Pūkẻnas, Mindaugas Balčiūnas
}

Lietuvos kūno kultūros akademija, Kaunas, Lietuva

\begin{abstract}
Kęstutis Matulaitis. Sporto magistras. Lietuvos kūno kultūros akademijos socialinių mokslų edukologijos krypties doktorantas. Moksliniu tyrimų kryptis — jaunujų krepšininkų daugiamečio sportinio rengimo optimizavimas.
\end{abstract}

\section{SANTRAUKA}

Tyrimu siekta nustatyti, ¿̇vertinti ir sudaryti 10-17 m. jaunuju krepšininku atletinio bei techninio parengtumo rangine skalę.

Tiriamaja imti sudarè 673 jaunieji 10-17 m. Arvydo Sabonio krepšinio mokyklos krepšininkai iš 8 skirtingo amžiaus grupiu: $10 \mathrm{~m} .(n=58), 11 \mathrm{~m} .(n=116), 12 \mathrm{~m} .(n=89), 13 \mathrm{~m} .(n=124), 14 \mathrm{~m} .(n=117), 15 \mathrm{~m} .(n=88), 16 \mathrm{~m}$. $(n=44), 17 \mathrm{~m}$. (n=37). Tyrimas buvo atliekamas 2004-2006 m. povaržybiniu laikotarpiu.

Taikytas testavimo metodas, kuriuo buvo vertinamas 10-17 m. jaunuju krepšininku atletinis (lokomocinis greitumas, greitumo jèga, koordinaciniai gebejjimai) ir techninis (kamuolio varymo ir judejjimo ginantis igüdžiu kokybè, metimu i krepš̉ iš skirtingu aikštès vietu tikslumas esant intensyviam fiziniam krūviui ir 30 baudos metimu tikslumas nesant intensyviam fiziniam krūviui) parengtumas.

Skaičiuotas aritmetinis rezultatu vidurkis ( $\bar{x})$, vidutinis standartinis nuokrypis (SD), vidurkiu skirtumo reikšmingumas pagal Stjudento t (Student t) nepriklausomu imčiu kriteriju. Skirtumas su galima mažesne nei 0,05 paklaida buvo vertinamas kaip statistiškai patikimas ( $p<0,05)$. Taip pat buvo naudojama ,,SPSS 12.0 for Windows “ programa, kuria sudarème atletinio ir techninio parengtumo rangines skales (puikiai 80_100\%; labai gerai 60_79\%; gerai 40-59\%; vidutiniškai 20—39\%; nepakankamai 0—19\%).

Išskirtini mūsu tirtu skirtingu amžiaus grupiu jaunuju krepšininku ūgio rodikliu skirtumai: 13-ais (5,1\%; p < 0,05, lyginant su dvylikmečiais) ir 15-ais metais (5,2\%; $p<0,05$, lyginant su keturiolikmečiais). Küno masès rodikliu skirtumai nustatyti lyginant vienuolikmečius su dešimtmečiais ( $<<0,05 ; 13,8 \%)$ ir penkiolikmečius su keturiolikmečiais $(p<0,05 ; 13,2 \%)$. Küno masė kiekvienais metais kito statistiškai reikšmingai $(p<0,05)$ : labiausiai kito vienuolikmečiu ir penkiolikmečiu — atitinkamai padidèjo 13,8 ir 13,2\%, lyginant su ankstesniais metais. Nevienodus skirtingu tiriamuju ūgio ir kūno masès skirtumus tarp 11 ir 12 metu krepšininku galejo lemti prepubertetinio ir pubertetinio laikotarpio sandūra.

Koju raumenu galingumas — skirtingai nei ügis ir kūno masé — labiausiai padidèjo dvylikmečiu (pubertetinio laikotarpio pradžioje: šuolio $\mathfrak{i}$ aukšt í iš vietos be ranku mosto padidejjo $12 \%-p<0,05$, lyginant su vienuolikmečiais). Lokomocinio greitumo rodikliai (20 m bejgimas iš aukšto starto) kaip ir koju raumenu galingumas, atliekant specifinio pobūdžio veiksmus (̌̌uolị aukštị su ranku mostu) labiausiai pakito penkiolikmečiu — atitinkamai 6,1\% ir 11,1\% (statistiškai reikšmingai, lyginant su keturiolikmečiais). Metais vèliau — šešiolikmečiu smarkiai $(p<0,05)$ pagerèjo koordinaciniai gebèjimai - 22,7\% (lyginant su penkiolikmečiais).

Technini parengtuma apibūdinantys skirtingu testu rodikliai kito nevienodai: statistiškai reikšmingai (lyginant su ankstesniais amžiaus metais, $p<0,05)$ kamuoli greičiau varè trylikmečiai $(7,2 \%)$, penkiolikmečiai geriau judèjo gindamiesi $(13,5 \%)$ ir mesdami baudos metimus (19,7\%), tačiau taikliausiai per 1 minutę kamuolí $\dot{z}$ krepš́ meté vienuolikmečiai (23,2\%). Tokius kitimus galejo lemti ir genotipiniai, ir fenotipiniai veiksniai.

Sudaryta jaunuju krepšininku (10-17 metu) atletinio ir techninio parengtumo ranginè skalè leis Lietuvos krepšinio treneriams ivertinti treniruojamu krepšininku parengtumo lygi.

Raktažodžiai: daugiametis sportinis rengimas, atletinis parengtumas, techninis parengtumas.

\section{IVADAS}

$\mathrm{K}$ repšinis - komandinis žaidimas (Stonkus, 2003), kuriam reikalinga įvairi judamoji veikla: greitumas, staigūs sustojimai, greiti judejimo krypties keitimai, pagreitejimai, ivvairūs šuoliai, greitas kamuolio varymas tai pat ìvairūs metimai ị krepši (Stonkus, 2003; Balčiūnas et al., 2006; Abdelkrim et al., 2007; Zwierko, Lesiakowski, 2007; Erčulj et al., 2009).

Jaunujų sportininkų daugiametis rengimas vientisas pedagoginis vyksmas, kuris trunka nuo 
8 iki 12 metuc, norint pasiekti geriausią rezultata (Ericsson, Charness, 1994; Karoblis, 1999; Balyi, Hamilton, 2004; Matulaitis, Stonkus, 2009). Svarbiausia, kad daugiamečiame procese sportinis rengimas vyktų kryptingai, planingai, būtų gerai organizuotas treniruotès vyksmas (Karoblis, 1999; Stonkus, 2003).

Daugiamečio sportinio rengimo vyksmas priklauso nuo jaunujų krepšininkų fizinių galimybių ir technikos veiksmų ivairiais amžiaus tarpsniais (Balčiūnas ir kt., 2009 a).

Vienas pagrindinių krepšininkų sportinio rengimo valdymo funkciju — sportinio parengtumo kontrolè. Siekiant kryptingai valdyti rengima, svarbu nuolat stebeti - nustatyti ir iqvertinti jaunujų krepšininkų daugiamečio rengimo atletinio bei techninio parengtumo rodiklių kaitą (Ljach, 2007; Balčiūnas ir kt., 2009 b).

Tyrimo objektas: jaunujų krepšininkų atletinis ir techninis parengtumas.

Tyrimo tikslas: sudaryti $10-17 \mathrm{~m}$. jaunųjų krepšininku atletinio ir techninio parengtumo ranginę skalę.

\section{TYRIMO METODIKA}

Tiriamieji. Tiriamają imti sudarè 673 jaunieji $10-17 \mathrm{~m}$. Arvydo Sabonio krepšinio mokyklos krepšininkai iš 8 skirtingo amžiaus grupių: $10 \mathrm{~m}$. $(\mathrm{n}=58), 11 \mathrm{~m} .(\mathrm{n}=116), 12 \mathrm{~m} .(\mathrm{n}=89), 13 \mathrm{~m}$. $(\mathrm{n}=124), 14 \mathrm{~m} .(\mathrm{n}=117), 15 \mathrm{~m} .(\mathrm{n}=88), 16 \mathrm{~m}$. $(\mathrm{n}=44), 17 \mathrm{~m} .(\mathrm{n}=37)$. Tyrimas buvo atliekamas 2004-2006 m., povaržybiniu laikotarpiu.

Testavimas. Jaunujų krepšininkų parengtumui nustatyti ir ivertinti buvo atliekami atletinio ir techninio parengtumo testai.

Atletinis parengtumas - sportininko judamujų, kompleksinių gebejjimu, judejjimo mokejjimų bei igūdžių išugdymo lygis, laiduojantis darnią ir veiksmingą veiklą per pratybas ir varžybas (Buceta, 2000; Stonkus, 2003; Balčiūnas ir kt., 2009 b).

Lokomocinio greitumo nustatymas. $20 \mathrm{~m}$ bėgimo iš aukšto starto testas (Brittenham, 1996; Apostolidis et al., 2004; Balčiūnas ir kt., 2009 b; Erčulj et al., 2009). 20 m nuotolio îveikimo trukme buvo registruojama NEWTEST matavimo iranga. Testo rezultatas - geriausias laikas iš triju bandymų.

Greitumo jègos ir koordinaciniu gebejimu testas. Šuolis i aukšti iš vietos be ranku mosto (Stapff, 2000; Balčiūnas ir kt., 2009; Erčulj et al., 2009) ir šuolis i aukšti su rankų mostu (Skernevi- čius ir kt., 2004; Balčiūnas ir kt., 2009 b). Šuolio i aukšti iš vietos be rankų mosto (rankas laikant ant liemens, šuolis pradedamas iš statinès padèties, kelio sąnario kampas $90^{\circ}$ ), rezultatas - geriausias bandymas iš trijų. Šuolio į aukštị iš vietos mojant rankomis rezultatas - geriausias bandymas iš trijų. Testų rezultatų skirtumas tarp šuolio su rankų mostu ir be mosto parode krepšininkų koordinacinius gebejjimus.

Techninis parengtumas. Jaunujų krepšininkų techninio parengtumo rodiklis - sensomotoriniai gebejjimai, kurie sportinio rengimo vyksme leidžia teisingai, tiksliai ir greitai atlikti technikos veiksmus (Stonkus, 2003; Ljach, 2007).

Kamuolio varymo testas (Johnson, Nelson, 1986; Balčiūnas ir kt., 2009 b) padeda nustatyti ir ivertinti kamuolio varymo igūdžiu kokybę. Testo rezultatas - laikas, sugaištas nurodytam keliui iveikti (iš dviejų bandymų geriausias).

1 minutès metimu $i$ krepš́ testas (Balčiūnas ir kt., 2009 b) leidžia nustatyti ir ivertinti metimų $i$ krepši iš skirtingų aikštès vietų tikslumą esant intensyviam fiziniam krūviui. Rezultatas — surinkta taškų suma.

Judejjimo ginantis testas (Johnson, Nelson, 1986; Ljach, 2007) nustato ir ívertina judejjimo ginantis kokybę. Testo rezultatas - laikas, sugaištas nurodytam keliui įveikti (iš dviejų bandymu geriausias).

30 baudos metimu testas (Balčiūnas ir kt., 2009 b) ivvertina baudos metimu veiksmu pastovumą ir tikslumą nesant intensyviam fiziniam krūviui. Rezultatas - metimų tikslumas.

Statistinė analizė. Skaičiuotas aritmetinis rezultatu vidurkis $(\bar{x})$, vidutinis standartinis nuokrypis (s), vidurkių skirtumo reikšmingumas - pagal Stjudento t nepriklausomų imčių kriterijų. Skirtumas su galima mažesne nei 0,05 paklaida buvo vertinamas kaip statistiškai patikimas $(\mathrm{p}<0,05)$. Taip pat buvo naudojama SPSS 12.0 for Windows programa, kuria sudareme atletinio ir techninio parengtumo rangines skales (puikiai $80-100 \%$; labai gerai $60-79 \%$; gerai $40-59 \%$; vidutiniškai 20-39\%; nepakankamai 0-19\%).

\section{REZULTATAI}

Mūsų tirtų aštuonių skirtingo amžiaus grupių $10-17 \mathrm{~m}$. krepšininku atletinio ir techninio parengtumo rodikliai pateikti 1 lentelèje.

Nors amžiaus grupių tiriamieji buvo skirtingi, vis dèlto pažymètini vienodi ūgio ir kūno masès rodiklių skirtumai tarp visų $10-17 \mathrm{~m}$. grupių, ly- 
ginant vyresniojo ir jaunesniojo amžiaus tiriamuju rodiklius.

Visgi kitų rodiklių skirtumai tarp amžiaus grupių buvo nevienodi. Išskirtini statistiškai reikšmingi $(\mathrm{p}<0,05)$ lokomocinio greitumo $(20 \mathrm{~m}$ bėgimo testo) rodikliu skirtumai, lyginant juos tarp 10 ir $11 \mathrm{~m} ., 12$ ir $13 \mathrm{~m} ., 13$ ir $14 \mathrm{~m} ., 14$ ir $15 \mathrm{~m}$. bei 16 ir $17 \mathrm{~m}$. amžiaus grupių krepšininkų. Greitumo jẻgos (šuolio su mostu ir šuolio be mosto) rodikliu skirtumai tarp amžiaus grupių vienodi, išskyrus tarp dešimtmečių ir vienuolikmečių krepšininkų. Vertinant koordinacinius gebejjimus, nustatyti statistiškai reikšmingi $(p<0,05)$ skirtumai tarp $10 \mathrm{ir}$ 12 m., 13 ir 17 m., lyginant vyresniuju amžiaus grupių krepšininkus su vienais metais jaunesniais krepšininkais (dešimtmečius su vienuolikmečiais, vienuolikmečius su dvylikmečiais, trylikmečius su keturiolikmečiais, keturiolikmečius su penkiolikmečiais, penkiolikmečius su šešiolikmečiais, šešiolikmečius su septyniolikmečiais) ir statistiškai nereikšmingi skirtumai $(\mathrm{p}>0,05)$ tarp 12 ir 13 metu tiriamujų, lyginant juos tokiu pat principu vienais metais vyresnius su jaunesniojo mažiaus krepšininkais.

Techninio parengtumo rodikliu skirtumai tarp amžiaus grupių tiriamujų taip pat nevienodi, kaip ir atletinio. Mažesni (statistiškai nereikšmingi $\mathrm{p}>$ $0,05)$ kamuolio varymo, judejimo ginantis, 30 baudos metimu testu skirtumai nustatyti tarp krepšininkų nuo penkiolikos metų amžiaus, lyginant vienais metais vyresnio amžiaus tiriamuosius su jaunesniais. Išskirtinis mažesnis vienos minutès testo rodiklių skirtumas, lyginant šešiolikmečių rodiklius su penkiolikmečiais $(\mathrm{p}>0,05)$.

\section{REZULTATŲ APTARIMAS}

Pagrindinis jaunujų krepšininkų daugiamečio rengimo kontrolès tikslas - sportinio rengimo optimizavimas atsižvelgiant i testavimų rodiklius, jų kaitą ir reikalavimus žaidejui skirtingais amžiaus tarpsniais (Leonardo et al., 2002). Todèl remdamiesi mūsų gautais $2004-2006$ m. testavimu rodikliais sudareme atletinio ir techninio parengtumo rangines skales (2, 3 lent.), kurios leistu treneriui greitai ir objektyviai ivvertinti žaidejo individualų atletini ir technini parengtumą.

Nustatytos mūsų tirtų skirtingo amžiaus 10 $17 \mathrm{~m}$. jaunuju krepšininku lokomocinio greitumo (20 m bègimo testo) nuosekliai didejjančios rodiklių reikšmès - nuo jauniausių tiriamuju (dešimtmečiu) iki vyriausių (septyniolikmečių) (1 lent.) $(\mathrm{p}<0,05)$. Didžiausias $6,1 \%(0,19 \mathrm{~s})$ rodikliu reikšmių padidejjimas (lyginant vyresniujų amžiaus grupių krepšininkus su vienais metais jaunesniais) nustatytas $14-15$ metais $(\mathrm{p}<0,05)$, mažiausias $1,1 \%(0,04 s)-10-11$ metais $(p<0,05)$. Penkiolikmečiu krepšininkų spartu greitumo rodikliu reikšmių padidejjimą, lyginant su kitų jaunesnių-

\begin{tabular}{|c|c|c|c|c|c|c|c|c|}
\hline \multirow{2}{*}{$\begin{array}{l}\text { Rodikliai } \\
(x \pm \text { SD) }\end{array}$} & \multicolumn{8}{|c|}{ Amžius, m. } \\
\hline & 10 & 11 & 12 & 13 & 14 & 15 & 16 & 17 \\
\hline \multirow{2}{*}{ Ūgis, cm } & 144,5 & 150,9 & 157,7 & 166,1 & 171,8 & 181,3 & 185 & 187,6 \\
\hline & $\pm 6,2$ & $\pm 6,98^{*}$ & $\pm 7,59 *$ & $\pm 9,31 *$ & $\pm 9,27 *$ & $\pm 8,79$ & $\pm 7,65$ & $\pm 5,7$ \\
\hline \multirow{2}{*}{ Kūno masè, kg } & 35,7 & 41,4 & 45,7 & 51 & 57,3 & 66,05 & 71,2 & 75,7 \\
\hline & $\pm 6,1$ & $\pm 7,95^{*}$ & $\pm 9,74^{*}$ & $\pm 10,27^{*}$ & $\pm 12,4^{*}$ & $\pm 10,46^{*}$ & $\pm 7,73^{*}$ & $\pm 7,46$ \\
\hline \multirow{2}{*}{ B 20, s } & 3,75 & 3,71 & 3,59 & 3,46 & 3,35 & 3,16 & 3,07 & 3,04 \\
\hline & $\pm 0,2$ & $\pm 0,19^{*}$ & $\pm 0,19^{*}$ & $\pm 0,18^{*}$ & $\pm 0,19^{*}$ & $\pm 0,12$ & $\pm 0,10^{*}$ & $\pm 0,12$ \\
\hline \multirow{2}{*}{ ŠsuM, cm } & 31,29 & 30,88 & 33,38 & 37,38 & 39,5 & 44,42 & 46,92 & 51 \\
\hline & $\pm 4,37$ & $\pm 4,4^{*}$ & $\pm 5,3^{*}$ & $\pm 5,36^{*}$ & $\pm 6,25^{*}$ & $\pm 4,19^{*}$ & $\pm 3,05^{*}$ & $\pm 5,63$ \\
\hline \multirow{2}{*}{ ŠbeM, cm } & 25,21 & 24,37 & 27,68 & 29,96 & 32,24 & 35,47 & 36,64 & 38,54 \\
\hline & $\pm 4,89$ & $\pm 4,77^{*}$ & $\pm 4,36^{*}$ & $\pm 4,22 *$ & $\pm 5,02 *$ & $\pm 3,51$ & $\pm 3,34$ & $\pm 4,89$ \\
\hline \multirow{2}{*}{$\mathrm{KG}, \mathrm{cm}$} & 6,08 & 5,35 & 5,08 & 6,11 & 6,45 & 7,76 & 10,04 & 12,46 \\
\hline & $\pm 0,9$ & $\pm 3,11 *$ & $\pm 2,39 *$ & $\pm 2,35$ & $\pm 2,2 *$ & $\pm 2,75^{*}$ & $\pm 0,91^{*}$ & $\pm 1,17$ \\
\hline \multirow{2}{*}{$\mathrm{KVT}$, s } & 9,69 & 9,75 & 9,47 & 8,83 & 8,81 & 8,37 & 8,32 & 8,15 \\
\hline & $\pm 0,86$ & $\pm 0,77^{*}$ & $\pm 0,68^{*}$ & $\pm 0,55$ & $\pm 0,54^{*}$ & $\pm 0,43$ & $\pm 0,57$ & $\pm 0,39$ \\
\hline \multirow{2}{*}{ JGT, s } & 9,83 & 9,82 & 9,35 & 9,28 & 8,84 & 7,79 & 7,78 & 7,88 \\
\hline & $\pm 0,8$ & $\pm 0,65^{*}$ & $\pm 0,8$ & $\pm 0,88^{*}$ & $\pm 0,98 *$ & $\pm 0,54$ & $\pm 0,58$ & $\pm 0,56$ \\
\hline \multirow{2}{*}{1 min, taškai } & 4,5 & 5,86 & 6,54 & 7,53 & 7,84 & 9,67 & 8,62 & 9,4 \\
\hline & $\pm 1,3$ & $\pm 3^{*}$ & $\pm 1,9$ & $\pm 2,32$ & $\pm 2,77^{*}$ & $\pm 3,3^{*}$ & $\pm 2,29 *$ & \pm 3 \\
\hline \multirow{2}{*}{$\begin{array}{l}30 \mathrm{~B} \text {, tikslūs } \\
\text { metimai }\end{array}$} & 13,07 & 14,38 & 14,49 & 17,42 & 18,37 & 22,87 & 22,71 & 23,46 \\
\hline & $\pm 5,52$ & $\pm 4,79 *$ & $\pm 4,52^{*}$ & $\pm 5,45^{*}$ & $\pm 4,61 *$ & $\pm 3,47$ & $\pm 4,36$ & $\pm 3,65$ \\
\hline
\end{tabular}

1 lentelè. Jaunųjų krepšininkų (10-17 m.) atletinis ir techninis parengtumas

Pastaba. B $20-20 \mathrm{~m}$ bègimo iš aukšto starto testas; ŠsuM - šuolis i aukšti iš vietos mojant rankomis testas; ŠbeM - šuolis į aukšti iš vietos be ranku mosto testas; KG - koordinaciniai gebejjimai (rezultatu skirtumas tarp testu) - ŠsuM ir ŠbeM; KVT - kamuolio varymo testas; JGT - judejjimo ginantis testas; $1 \mathrm{~min}-1 \mathrm{~min}$ metimu $i$ krepši testas; $30 \mathrm{~B}-30$ baudos métimu testas * — p $<0,05$, lyginant su ankstesnių metu rodikliais (patamsinta) 
2 lentelè. $\mathbf{1 0}-\mathbf{1 7} \mathbf{~ m}$. amžiaus krepšininkų atletinio parengtumo ranginė skalè

\begin{tabular}{|c|c|c|c|c|c|}
\hline \multirow[b]{2}{*}{$\begin{array}{l}\text { Tiriamųjų } \\
\text { amžius }\end{array}$} & \multirow[b]{2}{*}{ Ivertinimas } & \multicolumn{4}{|c|}{ Atletinio parengtumo ranginės skalès rodikliai } \\
\hline & & $\begin{array}{l}20 \mathrm{~m} \text { bẻgimas iš } \\
\text { aukšto starto, } \mathrm{s}\end{array}$ & $\begin{array}{l}\text { Šuolis ị aukštị } \\
\text { iš vietos mojant } \\
\text { rankomis, cm }\end{array}$ & $\begin{array}{l}\text { Šuolis į aukštį iš } \\
\text { vietos be rankų } \\
\text { mosto, cm }\end{array}$ & $\begin{array}{c}\text { Koordinaciniai } \\
\text { gebèjimai, cm }\end{array}$ \\
\hline \multirow{5}{*}{$\begin{array}{l}10 \mathrm{~m} . \\
(\mathrm{n}=58)\end{array}$} & Puikiai & $3,24-3,54$ & $41,2-34,7$ & $36,0-28,92$ & $9,2-6,6$ \\
\hline & Labai gerai & $3,55-3,68$ & $34,69-32,1$ & $28,91-25,99$ & $6,59-6,17$ \\
\hline & Gerai & $3,69-3,81$ & $32,09-30,4$ & $25,98-24,69$ & $6,16-5,86$ \\
\hline & Vidutiniškai & $3,82-3,90$ & $30,39-27,52$ & $24,68-21,91$ & $5,85-5,57$ \\
\hline & Nepakankamai & $3,91-4,16$ & $27,51-21,4$ & $21,90-14,0$ & $5,56-3,09$ \\
\hline \multirow{5}{*}{$\begin{array}{l}11 \mathrm{~m} . \\
(\mathrm{n}=116)\end{array}$} & Puikiai & $3,21-3,52$ & $40,9-34,7$ & $35,3-30,86$ & $13,9-7,3$ \\
\hline & Labai gerai & $3,53-3,63$ & $34,69-32,1$ & $30,85-28,19$ & $7,29-6,4$ \\
\hline & Gerai & $3,64-3,73$ & $32,09-29,6$ & $28,18-25,69$ & $6,39-5,24$ \\
\hline & Vidutiniškai & $3,74-3,82$ & $29,59-27,2$ & $25,68-22,39$ & $5,23-3,96$ \\
\hline & Nepakankamai & $3,83-4,28$ & $27,19-17,7$ & $22,38-12,8$ & $3,95--13,6$ \\
\hline \multirow{5}{*}{$\begin{array}{l}12 \mathrm{~m} . \\
(\mathrm{n}=89)\end{array}$} & Puikiai & $3,19-3,41$ & $47,39-38,97$ & $39,8-33,89$ & $15,93-6$ \\
\hline & Labai gerai & $3,42-3,49$ & $38,96-35,6$ & $33,88-30,99$ & $5,99-5,6$ \\
\hline & Gerai & $3,5-3,59$ & $35,59-33$ & $30,98-28,1$ & $5,59-5$ \\
\hline & Vidutiniškai & $3,6-3,69$ & $33,0-30,6$ & $28,09-25,69$ & $4,99-4$ \\
\hline & Nepakankamai & $3,7-4,2$ & $30,59-17,9$ & $25,68-14,33$ & $3,99--1,2$ \\
\hline \multirow{5}{*}{$\begin{array}{l}13 \mathrm{~m} . \\
(\mathrm{n}=124)\end{array}$} & Puikiai & $2,96-3,23$ & $56,6-41,7$ & $43,9-35,59$ & $14,10-8,4$ \\
\hline & Labai gerai & $3,24-3,34$ & $41,69-39,11$ & $35,58-32,73$ & $8,39-6,6$ \\
\hline & Gerai & $3,35-3,45$ & $39,10-36,6$ & $32,72-30,99$ & $6,59-5,7$ \\
\hline & Vidutiniškai & $3,46-3,52$ & $36,59-33$ & $30,98-27,99$ & $5,69-4$ \\
\hline & Nepakankamai & $3,53-3,92$ & $32,99-24,3$ & $27,98-20,6$ & $3,99--1$ \\
\hline \multirow{5}{*}{$\begin{array}{l}14 \mathrm{~m} . \\
(\mathrm{n}=117)\end{array}$} & Puikiai & $2,87-3,13$ & $54,7-44,25$ & $46,9-37,32$ & $10,9-7,9$ \\
\hline & Labai gerai & $3,14-3,23$ & $44,24-41,1$ & $37,31-34,99$ & $7,89-7,28$ \\
\hline & Gerai & $3,24-3,31$ & $41,09-39,5$ & $34,98-32,69$ & $7,27-6,65$ \\
\hline & Vidutiniškai & $3,32-3,40$ & $39,49-36$ & $32,68-29,49$ & $6,64-5,1$ \\
\hline & Nepakankamai & $3,41-3,99$ & $35,99-22,3$ & $29,48-21,4$ & $5,09--1,9$ \\
\hline \multirow{5}{*}{$\begin{array}{l}15 \mathrm{~m} . \\
(\mathrm{n}=88)\end{array}$} & Puikiai & $2,82-3,02$ & $64,2-49,6$ & $45,3-41,06$ & $12,94-9,5$ \\
\hline & Labai gerai & $3,03-3,09$ & $49,59-46,33$ & $41,05-38,09$ & $9,49-8,8$ \\
\hline & Gerai & $3,1-3,14$ & $46,32-44,1$ & $38,08-36,09$ & $8,79-8,2$ \\
\hline & Vidutiniškai & $3,15-3,23$ & $44,09-41,2$ & $36,08-33,69$ & $8,19-6,1$ \\
\hline & Nepakankamai & $3,24-3,38$ & $41,19-36,1$ & $33,68-30,0$ & $6,09--3,8$ \\
\hline \multirow{5}{*}{$\begin{array}{l}16 \mathrm{~m} . \\
(\mathrm{n}=44)\end{array}$} & Puikiai & $2,86-2,99$ & $56,31-51,6$ & $47,24-41,29$ & $12,1-10,5$ \\
\hline & Labai gerai & $3,0-3,05$ & $51,59-48,47$ & $41,28-38,68$ & $10,49-10,12$ \\
\hline & Gerai & $3,06-3,09$ & $48,46-47,5$ & $38,67-37,69$ & $10,11-9,8$ \\
\hline & \begin{tabular}{|l} 
Vidutiniškai \\
\end{tabular} & $3,1-3,16$ & $47,49-45,7$ & $37,68-35,69$ & $9,79-9,5$ \\
\hline & Nepakankamai & $3,17-3,80$ & $45,69-40,2$ & $35,68-28,4$ & $9,49-8,22$ \\
\hline \multirow{5}{*}{$\begin{array}{l}17 \mathrm{~m} . \\
(\mathrm{n}=37)\end{array}$} & Puikiai & $2,72-2,80$ & $62,5-56,98$ & $49,1-41,79$ & $14,9-13,5$ \\
\hline & Labai gerai & $2,81-2,91$ & $56,97-53$ & $41,78-38,79$ & $13,49-12,2$ \\
\hline & Gerai & $2,92-3,01$ & $52,99-50,3$ & $38,78-36,89$ & $12,19-12$ \\
\hline & Vidutiniškai & $3,02-3,11$ & $50,29-47,09$ & $36,88-33,89$ & $11,99-11,5$ \\
\hline & Nepakankamai & $3,12-3,28$ & $47,08-40,7$ & $33,88-30,5$ & $11,49-10,4$ \\
\hline
\end{tabular}

jų amžiaus skirtingų grupių tiriamaisiais, galëjo lemti augimo ir brendimo ypatumai (Malina et al., 2004). Mažesniam vienuolikmečiu greitumo rodiklių padidejjimui, lyginant su dešimtmečiais, itakos galejjo turèti ne tik prepubertetinio laikotarpio tiriamujų augimo ir brendimo ypatumai (Malina et al., 2004), bet ir taikyta treniravimo programa (Balyi, 2001).
Mūsų tiriamųų vidutiniai $20 \mathrm{~m}$ bėgimo testo rodikliai (1 lent.) buvo geresni už kitu autorių pateiktus įvairaus amžiaus rodiklius: $13-14 \mathrm{~m}$. 3,39 s (Karpowicz, 2006), 15 m. - 3,00 (Gore, 2000) ir 3,18 s (Santo et al., 1997), $16 \mathrm{~m}$. 3,2 s (Skernevičius ir kt., 2004), 17 m. - 3,08 s (Drinkwater et al., 2007). Vadinasi, galetume daryti prielaida, kad Lietuvos krepšinio trene- 


\begin{tabular}{|c|c|c|c|c|c|}
\hline \multirow[b]{2}{*}{$\begin{array}{l}\text { Tiriamụjų } \\
\text { amžius }\end{array}$} & \multirow[b]{2}{*}{ Ivertinimas } & \multicolumn{3}{|c|}{ Techninio parengtumo ranginės skalès rodikliai } & \multirow[b]{2}{*}{$\begin{array}{c}1 \text { minutės } \\
\text { metimų i krepši } \\
\text { testas, taškai }\end{array}$} \\
\hline & & $\begin{array}{c}\text { Judėjimo } \\
\text { ginantis testas, } s\end{array}$ & $\begin{array}{c}\text { Kamuolio } \\
\text { varymo testas, } \\
\mathrm{s} \\
\end{array}$ & $\begin{array}{c}30 \text { baudos } \\
\text { metimų testas, } \\
\text { tikslūs metimai }\end{array}$ & \\
\hline \multirow{5}{*}{$\begin{array}{l}10 \mathrm{~m} . \\
(\mathrm{n}=58)\end{array}$} & Puikiai & $8,13-9,03$ & $7,98-9,11$ & $18-28$ & $6-7$ \\
\hline & Labai gerai & $9,04-9,64$ & $9,12-9,42$ & $13-17$ & 5 \\
\hline & Gerai & $9,65-9,94$ & $9,43-9,69$ & $11-12$ & 4 \\
\hline & Vidutiniškai & $9,95-10,45$ & $9,7-10,42$ & $8-10$ & 3 \\
\hline & Nepakankamai & $10,46-11,55$ & $10,43-12,05$ & $3-7$ & $1-2$ \\
\hline \multirow{5}{*}{$\begin{array}{l}11 \mathrm{~m} . \\
(\mathrm{n}=116)\end{array}$} & Puikiai & $8,6-9,19$ & $8,1-8,89$ & $16-24$ & $8-16$ \\
\hline & Labai gerai & $9,2-9,59$ & $8,9-9,29$ & $11-15$ & $6-7$ \\
\hline & Gerai & $9,6-9,79$ & $9,3-9,59$ & $7-10$ & 5 \\
\hline & Vidutiniškai & $9,8-10,39$ & $9,6-10,29$ & $4-6$ & $3-4$ \\
\hline & Nepakankamai & $10,4-11,9$ & $10,3-11,7$ & $1-3$ & $1-2$ \\
\hline \multirow{5}{*}{$\begin{array}{l}12 \mathrm{~m} . \\
(\mathrm{n}=89)\end{array}$} & Puikiai & $6,8-8,79$ & $7,82-8,40$ & $22-27$ & $10-16$ \\
\hline & Labai gerai & $8,8-9,09$ & $8,41-8,82$ & $19-21$ & $7-9$ \\
\hline & Gerai & $9,1-9,49$ & $8,83-9,39$ & $16-18$ & 6 \\
\hline & Vidutiniškai & $9,5-9,99$ & $9,4-9,69$ & $13-15$ & 5 \\
\hline & Nepakankamai & $10,0-11,2$ & $9,7-11,1$ & $5-12$ & $2-4$ \\
\hline \multirow{5}{*}{$\begin{array}{l}13 \mathrm{~m} . \\
(\mathrm{n}=124)\end{array}$} & Puikiai & $7,4-8,39$ & $7,37-8,08$ & $23-27$ & $10-15$ \\
\hline & Labai gerai & $8,4-8,99$ & $8,09-8,49$ & $21-22$ & $8-9$ \\
\hline & Gerai & $9,0-9,49$ & $8,5-8,69$ & 20 & 7 \\
\hline & Vidutiniškai & $9,5-10,19$ & $8,7-9,09$ & $15-19$ & $5-6$ \\
\hline & Nepakankamai & $10,2-11,1$ & $9,1-9,9$ & $4-14$ & $3-4$ \\
\hline \multirow{5}{*}{$\begin{array}{l}14 \mathrm{~m} . \\
(\mathrm{n}=117)\end{array}$} & Puikiai & $7,1-8,09$ & $7,56-7,99$ & $24-29$ & $11-15$ \\
\hline & Labai gerai & $8,1-8,39$ & $8,0-8,29$ & $22-23$ & $9-10$ \\
\hline & Gerai & $8,4-8,89$ & $8,3-8,69$ & $20-21$ & 8 \\
\hline & Vidutiniškai & $8,9-9,59$ & $8,7-9,09$ & $17-19$ & $6-7$ \\
\hline & Nepakankamai & $9,6-11,6$ & $9,1-10,4$ & $9-16$ & $3-5$ \\
\hline \multirow{5}{*}{$\begin{array}{l}15 \mathrm{~m} . \\
(\mathrm{n}=88)\end{array}$} & Puikiai & $6,6-7,29$ & $7,5-7,93$ & $26-29$ & $13-18$ \\
\hline & Labai gerai & $7,3-7,59$ & $7,94-8,12$ & $24-25$ & $11-12$ \\
\hline & Gerai & $7,6-7,89$ & $8,13-8,29$ & $22-23$ & $9-10$ \\
\hline & Vidutiniškai & $7,9-8,19$ & $8,3-8,59$ & $20-21$ & 8 \\
\hline & Nepakankamai & $8,2-9,0$ & $8,6-9,5$ & $15-19$ & $4-7$ \\
\hline \multirow{5}{*}{$\begin{array}{l}16 \mathrm{~m} . \\
(\mathrm{n}=44)\end{array}$} & Puikiai & $6,5-7,39$ & $7,3-7,89$ & $26-29$ & $9-2$ \\
\hline & Labai gerai & $7,4-7,49$ & $7,9-8,29$ & $24-25$ & 8 \\
\hline & Gerai & $7,5-7,89$ & $8,3-8,49$ & $22-23$ & $6-7$ \\
\hline & Vidutiniškai & $7,9-8,39$ & $8,5-8,69$ & $19-21$ & 5 \\
\hline & Nepakankamai & $8,4-8,8$ & $8,7-9,4$ & $14-18$ & $2-3$ \\
\hline \multirow{5}{*}{$\begin{array}{l}17 \mathrm{~m} . \\
(\mathrm{n}=37)\end{array}$} & Puikiai & $6,7-7,39$ & $7,5-7,89$ & $27-30$ & $13 \mathrm{v} 17$ \\
\hline & Labai gerai & $7,4-7,79$ & $7,9-7,99$ & $25-26$ & $10-12$ \\
\hline & Gerai & $7,8-7,99$ & $8,0-8,09$ & $23-24$ & 9 \\
\hline & Vidutiniškai & $8,0-8,19$ & $8,1-8,39$ & $21-22$ & $7-8$ \\
\hline & Nepakankamai & $8,2-8,8$ & $8,4-9,1$ & $15-20$ & $5-6$ \\
\hline
\end{tabular}

riai atrinko gabius individus, o galbūt jie taike veiksmingas treniravimo programas, adekvačias ir büdingas jaunuju krepšininku amžiaus tarpsniams.

Greitumo jègai įvertinti ir nustatyti pasirinkome šuoli iš vietos i aukšti mojant rankomis ir be rankų mosto (Stapff, 2000). Nors tiriamieji ir buvo skirtingi, tačiau vertinant vyresniojo amžiaus
3 lentelè. 10-17 metų amžiaus krepšininku techninio parengtumo ranginè skalè 
$(3,3 \mathrm{~cm})$ rodiklių reikšmiu pagerèjimas nustatytas $11-12$ metais $(\mathrm{p}<0,05)$, o sumažèjimas $10-11$ metais $3,4 \%(-0,8 \mathrm{~cm} ; \mathrm{p}<0,05)$. Greitumo jègos rodikliai priklauso nuo kojų raumenu galingumo (Bompa, 1999). Tikètina, kad sparčiai gerejjant penkiolikmečiu jègos rodikliams (Fleck, Kraemer, 1997) kartu gerėjo ir galingumas, ypač reikšmingas jauniesiems krepšininkams (Balčiūnas ir kt., 2009 a).

Mūsų tiriamujų greitumo jègos rodikliai [šuolio i aukštị iš vietos be rankų mosto: $13 \mathrm{~m}$. $-27,5 \mathrm{~cm}$ (Kellis et al., 1999), $14 \mathrm{~m}$. - 30,8 cm (Kellis et al., 1999), $15 \mathrm{~m}$. - 31,1 cm (Kellis et al., 1999) ir 33,1 (Santo et al., 1997), 15-16 m. $-39,3 \mathrm{~cm}$ (Matavulj et al., 2002), 16 m. - 32,2 (Kellis et al., 1999); šuolio i aukštị iš vietos mojant rankomis rodikliai: $15-16 \mathrm{~m}$. $-53,9 \mathrm{~cm}$ (Trninic et al., 2001), $17 \mathrm{~m}$. - 62,0 cm (Drinkwater et al., 2007)] buvo geresni arba panašūs negu kitu tyrèjų tirtu to paties amžiaus krepšininkų. Tai, kad Lietuvos jaunieji krepšininkai pasaulio ir Europos čempionatuose sẻkmingai varžosi, galbūt žaidimo veiksmingumui reikšmingos itakos turi geresnis kojų raumenų galingumas (Santo et al., 1997; Woolstenhulme et al., 2006; Balčiūnas ir kt., 2009 a).

Koordinacinių gebejjimų (t. y. šuolio iš vietos su rankų mostu ir be rankų mosto testų rodikliu skirtumas) didžiausias rodiklių reikšmiu padidèjimas buvo $15-16$ metais $-22,7 \%(1,3 \mathrm{~cm}$; $\mathrm{p}<0,05)$, sumažejjimas $-10-11$ metais $13,7 \%(-0,7 \mathrm{~cm} ; \mathrm{p}>0,05)$. Tokius koordinaciniu gebejjimų rodiklių svyravimus galèjo lemti augimo ir brendimo fenotipiniai bei genotipiniai veiksniai (Malina et al., 2004).

Kamuolio varymo testas, kuris leido įvertinti žaidèjų kamuolio varymo igūdžių kokybę, parodé, kad 10-11 metais rodiklių reikšmių $0,5 \%$ $(0,05 \mathrm{~s})$ sumažejjimą (lyginant vienuolikmečius su dešimtmečiais) $(\mathrm{p}>0,05)$ galèjo lemti tai, kad šiuo amžiaus tarpsniu kamuolio varymo igūdžiai greitai keičiant kryptị dar nėra gerai susiformavę (Butautas, 2002; Stonkus, 2003). Didžiausias rodiklių $7,2 \%$ reikšmiu $(0,6 \mathrm{~s})$ pagerèjimas buvo tarp 12-13 m. tirtu krepšininku $(\mathrm{p}<0,05)$, nes šiuo laikotarpiu geriausiai lavejja lokomociniai gebèjimai ir juos lemiantys judamieji gebèjimai (greitumas, koordinacija, vikrumas), kurie nuolat lavinami leidžia atlikti jau susiformavusius krepšinio technikos veiksmus (Balčiūnas et al., 2009a).

Judejjimo ginantis testo rodikliai parodè, kad nuo $10-16$ metu mūsų tirtų aštuonių skirtingo amžiaus grupių tiriamujų rodiklių reikšmės didejjo, bet septyniolikmečiai judèjo blogiau nei šešiolikmečiai, nors ir statistiškai nereikšmingai ( $p>0,05 ; 1,4 \% ; 0,1 \mathrm{~s})$. Pagrindinè šio rodiklio blogejjimo priežastis galètų būti ta, kad jauniu amžiaus tarpsniu (17 m.) per specialuji rengimo laikotarpi galèjo būti skiriamas per mažas dèmesys pagrindiniam gynybos judejimo būdui lavinti (Klimantowicz, 1999).

Atliekant 1 minutès metimų i krepši testa, skirtingo amžiaus grupių tiriamujų rodiklių reikšmès menkai didèjo, bet išskirtinis padidèjimas buvo tarp 10-11 m. krepšininku $(23,2 \% ; 1,4$ taško; $\mathrm{p}<0,05)$, o sumažèjimas - lyginant šešiolikmečius su penkiolikmečiais $(12,2 \% ; 1,0$ taško; $\mathrm{p}<0,05)$. Mūsų tirtų $10-15 \mathrm{~m}$. jaunujų krepšininku 30 baudos metimu testo rodikliu reikšmès statistiškai reikšmingai didèjo $(\mathrm{p}<0,05)(1$ lent.), bet nuo $15-17 \mathrm{~m}$. didejo vos $2,5 \%(0,59$ tikslaus metimo).

Tikètina, kad jaunujų skirtingo amžiaus 10$14 \mathrm{~m}$. grupių krepšininkų techninio parengtumo rodiklių reikšmių (metimų iš skirtingų aikštès vietų, baudos metimų) didejjimą labiausiai skatino šiam amžiaus tarpsniui būdinga technikos veiksmų treniravimo programa. Manytume, kad dèl tos pačios priežasties jau vèlesniais $15-17$ metais, kada yra baigiamas techninis rengimas, tiriamųjų techninio parengtumo rodikliai tik šiek tiek padidejja ar net sumažejja (Klimontowicz, 1999; Stonkus, 2003).

Nustatytą jaunujų krepšininku atletinio ir techninio parengtumo rodiklių reikšmių didejjimą galėjo lemti treniravimas (Karpowicz, 2006; Drinkwater et al., 2007), biologinès brandos (Balyi, Hamilton, 2004), kartu ir genetiniai ypatumai (Bouchard et al., 1997). Visu ivvardytu veiksniu poveikis kiekvienam individui yra individualus (Bompa, 1999). Norint nustatyti ir ivertinti jaunujų krepšininkų atletinio ir techninio parengtumo lygi per kiekvieną daugiamečio rengimo (10-17 metus) tarpsni labai svarbu sudaryti parengtumo ranginę skalę (Johnson, Nelson, 1986; Stonkus, 2003; Drinkwater et al., 2008).

\section{IŠVADOS}

Sudaryta jaunujų krepšininkų (10-17 m.) atletinio ir techninio parengtumo ranginè skale $(2$, 3 lent.) leis Lietuvos treneriams ivertinti treniruojamų krepšininkų parengtumo lygi. 


\section{LITERATŪRA}

Abdelkrim, N. B., El Fazaa, S., El Ati, J. (2007). Time motion analysis and physiological data of elite under 19-year-old basketball players during competition. British Journal of Sports Medicine, 41, 69-75.

Apostolidis, N., Nassis, G. P., Bolatoglou, T., Geladas, N. D. (2004). Physiological and technical characteristics of elite young basketball players. Journal of Sports Medicine and Physical Fitness, 44 (2), 157.

Balčiūnas, M., Matulaitis, K., Stonkus, S. (2009 a). Ivairaus amžiaus krepšininkų pagrindiniai fizinio ir techninio parengtumo rodikliai ir ju kaita. Sporto mokslas, 56 (2), 58-64.

Balčiūnas, M., Stonkus, S., Abrantes, C., Sampaio, J. (2006). Long term effects of different training modalities on power, speed, skill and anaerobic capacity in young male basketball players. Journal of Sports Science and Medicine, 5, 163-170.

Balčiūnas, M., Stonkus, S., Garastas, V. (2009 b) Krepšininku parengtumas: nustatymas ir juertinimas. Kaunas: LKKA.

Balyi, I., Hamilton, A. (2004). Long-Term Athlete Development: Trainability in Childhood and Adolescence. Windows of Opportunity. Optimal Trainability. Victoria: National Coaching Institute British Columbia \& Advanced Training and Performance Ltd.

Balyi, I. (2001). Sport system building and long-term athlete development in Canada. The situation and the solutions. In Coaches Report. The Official Publication of the Canadian Professional Coaches Association, 8 (1), $25-28$.

Bompa, T. O. (1999). Periodization: Theory and Methodology of Training. Champaign: Human Kinetics.

Bouchard, C., Malina, R., Pérusse, L. (1997). Genetics of Fitness and Physical Performance. Champaign: Human Kinetics.

Brittenham, G. (1996). Complete Conditioning for Basketball. USA: Human Kinetics.

Buceta, J. M. (2000). Organising Training Session. Basketball for Young Players. Madrid: FIBA. P. 83-100.

Butautas, R. (2002). Vienalaikio poveikio metodo veiksmingumas, rengiant jaunuosius krepšininkus: daktaro disertacija. Kaunas: LKKA.

Drinkwater, E. J., Hopkins, W. G., McKenna M. J., Hunt P. H., Pyne, D. B. (2007). Modelling age and secular differences in fitness between basketball players. Journal of Sports Sciences, 25 (8), 869-878.

Drinkwater, E. J., Pyne, D. B., McKenna, M. J. (2008). Design and interpretation of anthropometric and fitness testing of basketball players. Sports Medicine, 38 (7), $565-578$

Erčulj, F., Blas, M., Čoh, M., Bračič, M. (2009). Differences in motor abilities of various types of European young elite female basketball players. Kinesiology, 41, 203-211.

Ericsson, K. A., Charness, N. (1994). Its structure and acquisition. American Psychologist, 8, 725-747.

Fleck, S. J., Kramer, W. J. (1997). Designing Resistance Training Programs. Champaign, IL: Human Kinetics.

Gore, Ch. J. (2000). Physiological Tests for Elite Athletes. Champaign, IL: Human Kinetics.
Johnson, B., Nelson, J. (1986). Practical Measuremens for Evalution in Physical Education. USA: Burgess Publishing.

Karoblis, P. (1999). Sporto treniruotès teorija ir didaktika. Vilnius: Egalda.

Karpowicz, K. (2006). Interrelation of selected factors determining the effectiveness of training in young basketball players. Human Movement, 7 (2), 130-146.

Kellis, S. E., Tsiskaris, G. T., Nokopolou, M. D., Mousikou, K. C. (1999) The evaluation of jumping ability of male and female basketball players according to their chronological age and major leagues. Journal of Strength and Conditioning Research, 13 (1), 40-46.

Klimantowicz, W. (1999). Koszykowka. Warszawa: Centralny oszrodek sportu.

Leonardo, A., Teodora, P., Adriana, A. (2002). The Modeling of Physical Preparation's Content in Basketball Game (Juniors): $7^{\text {th }}$ Annual Congress of the European College of Sport Science. Athens, 24-26 July.

Ljach, W. (2007). Koszykowka. Krakow: University School of Physical Education.

Malina, R. M., Bouchard, C., Bar-Or, O. (2004). Growth, Maturation, and Physical Activity. Champaign, IL: Human Kinetics.

Matavulj, D., Kukolj, M., Ugarkovic, D., Tihanyi J., Jaric, S. (2001). Effects of plyometric training on jumping performance in junior basketball players. The Journal of Sport Medicine and Physical Fitness, 41, 159-164.

Matulaitis, K., Stonkus, S. (2009). Ivairaus amžiaus krepšinio komandu žaidimo rezultatyvumo ir metimu ivairovès rodiklių analizè. Ugdymas. Küno kultūra. Sportas, 72 (1), 54-64.

Santo, E., Janeira, A. M., Maia, J. A. (1997). Effects of specific training and detraining in explosive strength: A study on young male basketball players. Revista Paulista de Educação Física, 11 (2), 116-127.

Skernevičius, J., Raslanas, A., Dėdelienè, R. (2004). Sporto mokslo tyrimu metodologija. Vilnius: Lietuvos sporto informacijos centras.

Stapff, A. (2000). Protocols for the physiological assessment of basketball players. In C. Gore (Ed.), Physiological Tests for Elite Athletes (pp. 224-237). Champaign, IL: Human Kinetics.

Stonkus, S. (2003). Krepšinis. Istorija, teorija, didaktika. Kaunas: LKKA.

Trninic, S., Markovic, G., Heimer, S. (2001). Effects of developmental training of basketball cadets realised in the competitive period. Collegium Antropologicum, 25 (2), 591—604.

Woolstenhulme, M. T., Griffiths, C. M., Woolstenhulme, E. M., Parcell, A. C. (2006). Ballistic stretching increases flexibility and acute vertical jump height when combined with basketball activity. Journal of Strength and Conditioning Research, 20 (4), 799-803.

Zwierko, T., Lesiakowski, P. (2007). Selected parameters of speed performance of basketball players with different sport experience levels. Studies in Physical Culture and Tourism, 14, 307-312. 


\title{
LONG-TERM DEVELOPMENT OF PHYSICAL FITNESS AND TECHNICAL FITNESS IN BASKETBALL MALE PLAYERS AGED 10-17 YEARS
}

\author{
Kęstutis Matulaitis, Antanas Skarbalius, Kazimieras Pūkẻnas, Mindaugas Balčiūnas \\ Lithuanian Academy of Physical Education, Kaunas, Lithuania
}

\begin{abstract}
The aim of the research was to determine, measure and form young basketball players' (10 to 17 years) scale of physical and technical fitness. It might be used to organize training more efficiently.

673 young basketball players (10 to 17 years) of Arvydas Sabonis Basketball School participated in the research. A total of eight age groups of were tested: 10 year-old $(n=58), 11$ year-old $(n=116), 12$ year-old $(\mathrm{n}=89), 13$ year-old $(\mathrm{n}=124), 14$ year-old $(\mathrm{n}=117), 15$ year-old $(\mathrm{n}=88), 16$ year-old $(\mathrm{n}=44)$ and 17 year-old players $(n=37)$. The tests were carried out after the playing season.

The testing method was used to evaluate athletic (lokomotive speed, the force of quickness, coordination) and technical (the quality of dribbling and defensive movement, shooting from various distances with physical load and 30 free throw shots without physical load) fitness of 10 to 17 year-old basketball players.

After the test the average $(\bar{x})$, standard error (SD) and significance (Student $\mathrm{t}$ test) werw established. The difference of less than the error of $\mathrm{p}<0.05$ was thought as statistically relevant. The SPSS 12.0 for Windows software was used to form the range scale of athletic and technical fitness (excellent $80-100 \%$; very good $60-79 \%$; good $40-59 \%$; average $20-39 \%$; poor $0-19 \%$ ).

The height of the tested basketball players was increasing constantly the greatest in their 13 th $(5.1 \%$; $\mathrm{p}<0.05$ - compared to 12 year-old) and 15 th $(5.2 \% ; \mathrm{p}<0.05$ - compared to 14 year-old) year. The weight growth was also statistically significant - especially in the players' 11 th and 15 th years of age the increase in growth was 13.8 ir $13.2 \%$ respetively compared to the previous year. Different changes in height and weight of 11 and 12 year-old players might be affected by the juncture of pre-pubery and puberty.

The biggest increase of power of leg muscles, on the other hand, was in the 12th year of the players (at the start of the puberty period; high jump without hand swing results increased by $12 \%-\mathrm{p}<0.05$, compared to 11 year-olds). Locomotive speed results $(20 \mathrm{~m}$ sprint from high start) and leg muscle power in specific activities (high jump with swing of hands) increased the most in the 15th year -6.1 and $11.1 \%$ respectively (compared to 14 year-olds). The tests showed that 16 year-olds' coordination results increased by $22.7 \%$ compared to 15 year-old players $(\mathrm{p}<0.05)$.

The technical fitness tests results changed variously: the speed of the 13 year-old players' dribbling increased significantly $(\mathrm{p}<0.05)$. However, 15 year-olds were better at movements' on defense $(13.5 \%$ increase) and at free throw shooting (an increase of 19.7\%), while 11 year-old basketball players managed to improve the most in 1-minute shooting drills (23.2\% increase). Genotyphic and phenotyphic factors might have influenced those results.

The formed scale of young basketball players' (10 to 17 year-old) physical and technical fitness may give the possibility for Lithuanian basketball coaches to assess the fitness of players.
\end{abstract}

Keywords: long-term development, physical fitness, technical fitness.

Gauta 2010 m. kovo 15 d.

Received on March 15, 2010

Priimta 2010 m. gegužès $31 \mathrm{~d}$.

Kęstutis Matulaitis

Accepted on May 31, 2010

Lietuvos kūno kultūros akademija

(Lithuanian Academy of Physical Education)

Sporto g. 6, LT-44221 Kaunas

Lietuva (Lithuania)

Tel +37067919290

E-mail kestutis.matulaitis@yahoo.com 